\title{
Ralph Bunche and African Studies: Reflections on the Politics of Knowledge
}

\author{
Pearl T. Robinson
}

Editors' note: This article originally was presented as the Presidential Address at the African Studies Association 50th Anniversary Meeting, October 2007, New York City

"The dominant force in modern Africa is that of change." These words, penned by Ralph Bunche in his 1934 doctoral dissertation (72), prefigured the ethos of what would come to be called, by the 1950s, the new field of African studies. Bunche's thesis, written for Harvard's Department of Government, offered a comparative analysis of French colonial administration in Dahomey (a colony under French rule) and Togoland (a League of Nations Mandate administered by France). His treatment of the subject wove together debates about colonial administration, race relations, and the responsibilities of the international community toward dependent peoples and non-self-governing territories-with the ultimate goal of producing a

\footnotetext{
African Studies Review, Volume 51, Number 1 (April 2008), pp. 1-16
}

Pearl T. Robinson is an associate professor of political science at Tufts University, where she directed the Program in International Relations from 1994 to 2001. Her co-edited volume (with Elliott P. Skinner), Transformation and Resiliency in Africa (Howard University Press, 1983) examines the contributions of African American Africanists to African studies. She is a former chair of the SSRC/ACLS Joint Committee on African Studies (1994-96) and was a member of the African Studies Association's Herskovits Award committee from 2001 to 2004. Robinson was a visiting professor at Makerere University in 1997-98 and at the University of Dar es Salaam in 2002-3. She has served on the boards of Oxfam-America (1977-86), TransAfrica (1993-96), and the Council on Foreign Relations' Center for Preventive Action (1995-98), and was a member of the American Political Science Association's Committee on Profession Ethics in 2001-4. Her current project is an intellectual biography of Ralph Bunche. 
work of both academic and policy relevance. As a fundamental principle, Bunche insisted that the study of Africa should not be divorced from the study of the larger sweep of world history and global change because "the African is exposed to the pressure of forces of an outside world which is itself in process of transformation" (1934:73). Moreover, in a stance that was unusual for its time, Bunche set out to study Africa from the perspective of the African.

As we pause to mark the fiftieth anniversary of the establishment of the African Studies Association (ASA) in the United States, real world events are once again forcing scholars concerned with the continent to take seriously the notion that our work should have both academic and policy relevance. The human rights theme of this year's annual program, as well as issues addressed in the featured round tables and plenary sessions-issues such as China's new Africa policy, the United Nation's Millennium Development Villages, and reparations for the slave trade-reflect the ASA's commitment to providing a space where producers of basic knowledge about Africa can meet and exchange views with civic engagement communities and policymakers.

The ASA at fifty now has a deeper appreciation for the fact that it is important not only to study Africa from the perspective of the African, but also to take the time necessary to listen to African perspectives, and to give a megaphone to a broad spectrum of African voices at our annual meetings. The Bashorun M. K. O. Abiola Lecture and the Women's Caucus Lecture are now institutionalized as platforms for inviting distinguished African speakers to address the ASA. This year's Current Issues Plenary featured African perspectives on U.S. policy toward the continent. The Social Science Research Council brought together a panel of African public intellectuals to discuss the situation in Darfur. And an ASA Board-sponsored roundtable assessing the legacy of Kofi Annan provided an opportunity to hear from several distinguished African diplomats with long experience at the United Nations. If Ralph Bunche were alive today, I dare say he would be here with us, reflecting on Africa's trials and triumphs, analyzing the various mechanisms of globalization, and urging us to amplify the many and varied African voices for peace, development, and global equity.

Let's flash back for a moment to March 1957. Had it not been for the pull of historic events on the African continent, Ralph Bunche might well have been present for the ASA's founding meeting here in New York City. After all, he worked just down the street at the United Nations secretariat. But the Suez crisis had erupted a few months earlier, and Bunche was overseeing the practical arrangements for setting up a U.N. Emergency Force (the first peacekeeping operation of its kind) in Gaza. On route to the Middle East, he stopped in Accra to represent the United Nations at the independence ceremonies of the Gold Coast (Ghana) on March 7, 1957. There, among the many dignitaries, pan-Africanists, and civil rights activ- 
ists, Bunche saw his old friend and fellow academic Melville Herskovits of Northwestern University. After the festivities Herskovits left for New York to attend the formal launch of the ASA and was named the association's first president. Bunche flew to the Gaza Strip and on to Cairo for negotiations with Egypt's President Nasser (Gershenhorn 2004:195-96; Urquhart 1993:277-85). The worlds of the diplomat and the scholar intersect, and are not as far apart as one might assume.

Ralph Johnson Bunche, the 1950 Nobel Peace laureate, is best known for his work as a diplomat. He is also hailed as the principal architect of U.N. peacekeeping. Some will remember his pivotal role on the staff of the Carnegie-Myrdal study that produced the landmark book An American Dilemma: The Negro Problem and Modern Democracy (1944). Yet Bunche spent the formative years of his professional life as an academic who specialized in Africa. In the 1930s, during his tenure as chair of the political science department at Howard University, he sketched out the elements of a new paradigm for the study of late-colonial Africa. Combining a zeal for social engineering with a commitment to empirical social science, he sought to bring the latest theories to bear on African problems. In doing so, he insisted on the importance of understanding the African's point of view.

Over the course of his career, Bunche both valued and problematized "the perspective of the native." He believed that a deep, empirically based knowledge of Africa provided a better understanding of the vital interests of the general population than many of the positions articulated by political authorities on their behalf. This mindset was put to good use when he oversaw the establishment of the U.N. Trusteeship Council and, as director, worked out protocols for the annual collection of data on political, economic, and social developments in the Trust territories. He argued that the international system needed to acquire disinterested, objective data in order to measure human progress and to assist in social, economic, and political development. In 1960, while heading the U.N. Operation in the Congo (UNOC), Bunche assessed the new Congolese leadership to be wanting, and came to believe that he was the better judge of the best interests of the Congolese people. That intellectual journey bears lessons for all of us as Africanists.

The Ralph Bunche centenary celebrations in 2003 and 2004 produced a flurry of new scholarship designed to reintroduce a man who was lauded as one of the great internationalists of the twentieth century. The basic Bunche texts of the 1990s-Benjamin Rivlin's edited volume Ralph Bunche: The Man and His Times (1990), Brian Urquhart's Ralph Bunche: An American Odyssey (1993), Charles Henry's Ralph Bunche: Model Negro or American Other? (1999), and Robert Edgar's An African American in South Africa (1992)found new audiences. Bunche's contributions to the discipline of political science, his posture as a public intellectual, his vocation as a political consultant and race relations expert, his encounter with McCarthyism, his 
troubled relationship with the Congo's Patrice Lumumba, and his role in transforming the concept of international trusteeship from a caretaker operation to the project of decolonization have been rediscovered and examined through contemporary lenses. Even so, with the notable exception of Edgar's excellent treatment of Bunche's time spent in South Africa honing the techniques of ethnographic fieldwork on an SSRC post-doc, Ralph Bunche, the Africanist, remains largely unknown.

\section{Ralph Bunche, the Africanist}

I begin my examination with three questions: What should be the relevant knowledge about Africa? Who gets to make that determination, and on what basis? Let's look at how Bunche's answers to these questions changed over time:

Doctoral thesis, January 1, 1934: Too often, ... in the earnest consideration of Africa and her myriad problems, sight is lost of the African... The solution of the problem of the future of Africa is to be found in the determination of the eventual relationships that will prevail between the Africans and other peoples.

Congo cable, September 1, 1960: I... react very strongly against their endorsement of thesis that there has been lack of consultation.... Of course we can satisfy them by lip service to consultation even in cases where Govt. is utterly incompetent to judge or utterly incapable of acting but... the ultimate responsibility must be ours as we cannot, with open eyes, in order to placate Govt., do things we know to be harmful to best interests of the Congo. Indeed! ${ }^{1}$

I use the term "Africanist" to refer to someone who engages in the production and validation of knowledge about Africa on the basis of primary source data and empirically grounded field research. ${ }^{2}$ Ralph Bunche was an academic who did fieldwork in Africa, wrote about Africa, and in the late 1920s introduced into the Howard University curriculum courses about imperialism, international law and politics, and colonial administration in Africa. Bunche, the Africanist, produced data that challenged the accepted wisdom of recognized authorities and served as a basis for offering his own policy prescriptions. Close scrutiny reveals both the tenacity of his beliefs and the real-world consequences of his conviction that intellectuals skilled in the tools of modern social science are equipped to play a directive role in restructuring society (Holloway 2002:16-17). This mindset connected his Africanist scholarship with trajectories forged and followed in his work with the United States government as an Africa policy analyst during World War II, and for the duration of his career with the United Nations.

Bunche's empirically grounded work on Africa is dispersed in a wide 


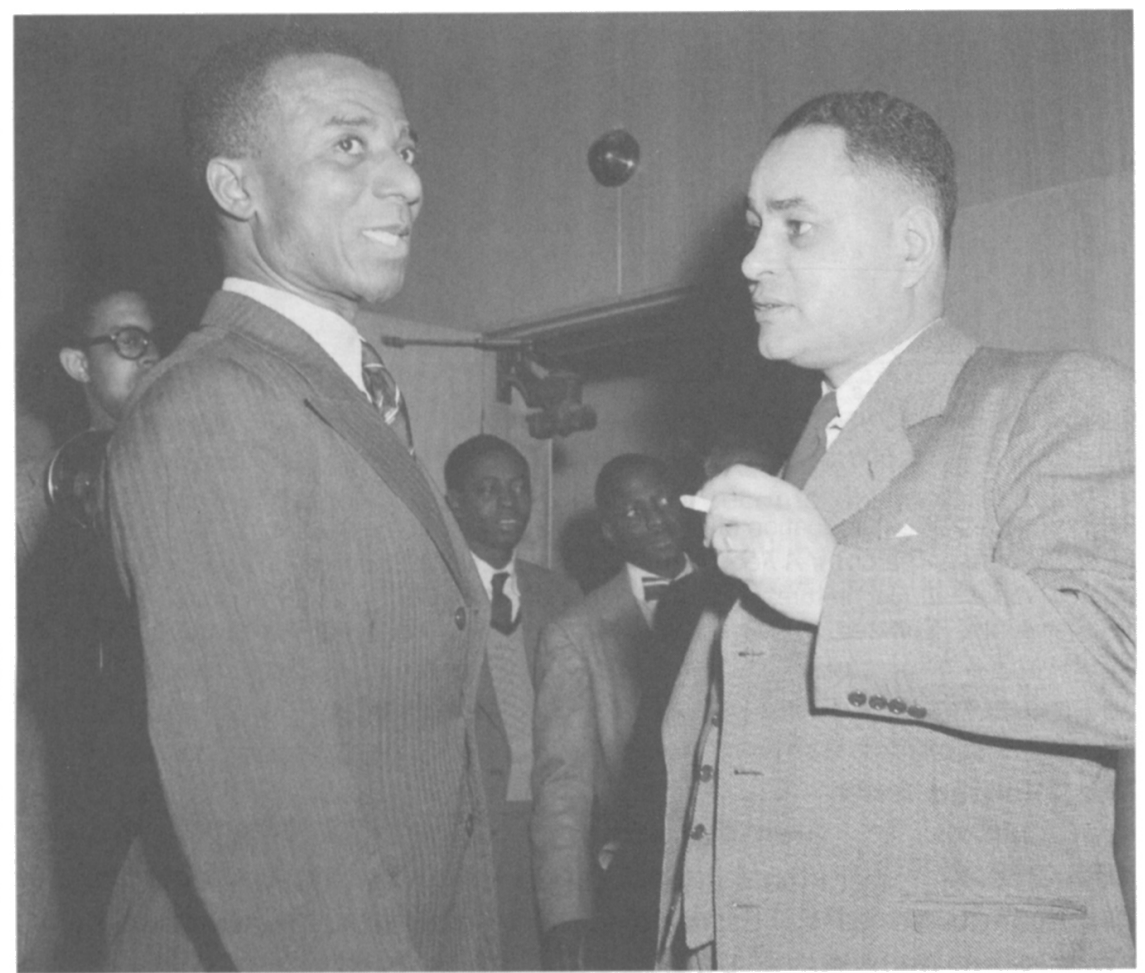

Sylvanus E. Olympio of Togoland, left, spokesman for the All-Ewe Conference, and the first petitioner to appear before a full council of the United Nations, talks with Ralph J. Bunche, director of Trusteeship Division, before the 11th meeting of the Trusteeship Council. Lake Success, New York, December 8, 1947. Photograph courtesy of the United Nations.

variety of relatively obscure sites: his Harvard dissertation; articles and book reviews published largely in Negro journals; thousands of photographs shot during episodes of field research in Dahomey, Togo, South Africa, Kenya, and on safari through Uganda, Congo, Tanganyika, and Kenya; travel notes chronicling his research in Kenya and South Africa; ethnographic film footage; plus the formal documentation of interest articulation by subject peoples collected during his directorship of the U.N. Trusteeship Council. Taken together, these materials constitute the elements of the paradigm that informed Bunche's Africanist scholarship. That paradigm-grounded in economic determinism--emphasized the problems posed by colonial policies, imperialism, and the changing status of the contemporary African population. For Bunche, these were the defining issues of late-colonial Africa. And with the conviction of a man who knows that he is right, he insisted that these matters should constitute the central terrain of modern African studies. 


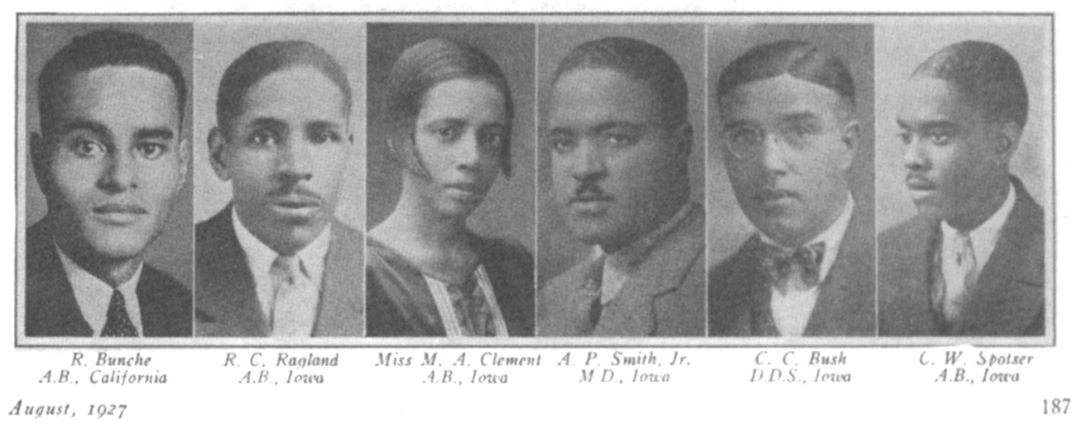

Ralph Bunche's UCLA graduation picture (far left) appeared in the August 1927 edition of the NAACP's journal, The Crisis: A Record of the Darker Races. The publication's editor, W.E.B. Du Bois, ran an annual feature, "The College Educated Negro," as a way to showcase the Talented Tenth. Reprinted, by permission, from The Crisis: A Record of the Darker Races.

\section{The Talented Tenth}

A Phi Beta Kappa graduate in political science from UCLA, Bunche fell under the influence of W.E.B. Du Bois's theory of the so-called Talented Tenth while still in high school. Du Bois's now classic 1903 essay, "The Talented Tenth," presents the case for liberal education of a critical segment of African Americans who would be equipped to provide the leadership necessary for race progress. Assuming that "the Negro race, like all other races, is going to be saved by its exceptional men," Du Bois argued that roughly a tenth of the black population in the U.S. should receive a liberal arts education that emphasizes "intelligence, broad sympathy, knowledge of the world that was and is, and of the relation of men to it."

The Talented Tenth was defined largely, though not entirely, by educational training coupled with the special mission of racial uplift. Less than a generation out of slavery, the relatively few African Americans privileged to receive higher education were encouraged to become "leaders of thought and missionaries of culture among their people" (Du Bois 1903). Like many of his generation, Bunche answered the call. In fact, shortly before delivering the valedictory address at UCLA's 1927 Commencement exercises, he wrote a letter to Du Bois introducing himself as one of the Talented Tenth: "Since I have been sufficiently old to think rationally and to appreciate that there is a 'race problem' in America,... I set as the goal of my ambition service to my group. I am even now fulfilling that ambition." ${ }^{3}$ Bunche did not only embrace the Talented Tenth as a matter of self-identification; he also transported the concept to Africa-first, via his academic research, and later, through his work with the United Nations. 


\section{Hypothesis-Testing in French Colonial West Africa: Bunche and Buell}

Bunche, the social scientist, was empirically driven and partial to analyses designed for hypothesis testing. He engaged the world of big ideas, and in so doing he sought to effect change. Bunche, the Africanist, was an iterative thinker. He identified fault lines in works of high repute and then, using his own data (always generated by field studies), he challenged prevailing certainties with the careful phrasing of a skillful draftsman.

The subject of the dissertation, "French Administration in Togo and Dahomey," was suggested by Raymond Leslie Buell, a specialist in international relations and comparative politics, who taught in Harvard's government department before leaving in 1927 to become director of research (later president) of the New York-based Foreign Policy Association. His monumental two-volume work, The Native Problem in Africa, was published in 1928. That same year Buell informed the Howard University philosopher Alain Locke that he wished to see "an American Negro take a thorough study of the situation in Africa." 4 Locke promoted his young colleague, Ralph Bunche. Buell then went to extraordinary ends to facilitate Bunche's access to sensitive colonial records.

Bunche developed a comparative research design to test Buell's hypothesis that colonized people fared better under the League of Nations' Mandate system than under pure colonialism. He traveled to Paris and London to consult records of French and British colonial administration, then to Geneva to the office of the League's Mandate system. Fieldwork in Dahomey and Togo enabled him to gather data on the internal dynamics of French colonial administration in the two settings. Finding little difference between the two, he then marshaled evidence to argue that French economic interests shaped colonialism in both Dahomey and Togo. For this groundbreaking study, Bunche won Harvard's Toppan Prize for the year's best dissertation in the field of government. In recognition of the pioneering nature of this work, Harvard's government department created a new subfield called "International Relations with Special Attention to the Government of Dependencies." 5

Strikingly, the dissertation actually rejects three major arguments advanced by Buell in The Native Problem: (1) that in the French mandates the military, educational, and native policies were better than in French colonies; (2) that legislation designed to build separate white and black communities in South Africa would reduce racial conflict; and (3) that Indirect Rule should be seen as an experiment in self-determination. But Bunche treated only the first proposition as a formal hypothesis that he tested with hard data.

In support of the argument that mandate administration was preferable to colonial administration, Buell provided comparative statistics on taxes, conscription, and social services in the French Mandates of Togo and 


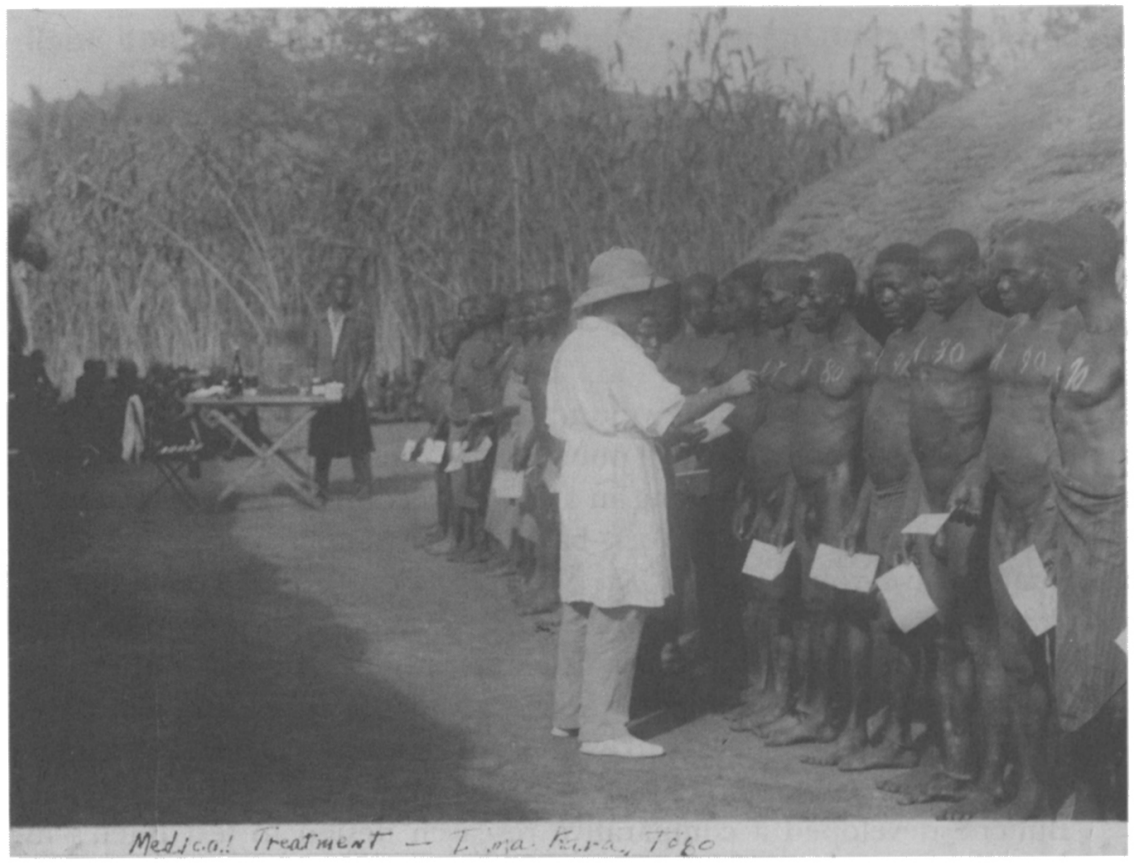

While doing dissertation fieldwork in 1932, Bunche collected this photo, taken by Agence Cameroun-Togo, to document the medical advances brought by the French to combat sleeping sickness among the Togolese population under their League of Nations Mandate. Photograph courtesy of the Schomburg Center for Research in Black Culture.

the Cameroons, and then cited the views of a few Togolese elites who compared their situation with that of relatives in the neighboring French colony of Dahomey. Bunche collected data in these same areas of colonial activity. However, he contended that the most valid data were the native populations' own perceptions of whether the difference affected their social, political, and economic welfare. Holding the domestic arena constant, he sought to determine whether ordinary Togolese perceived a difference in their situation following the change in Togo's status from a German colony to a French mandate. Conclusions drawn from these two methods of analysis reveal dueling perspectives:

Buell: French military policy in the mandates differs vitally from French policy in the colonies proper. This difference is appreciated by the most pro-French natives in Lomé, the capital of Togo, who declare that they would not live in the neighboring colony of Dahomey because of the military obligations to which their relatives there must submit. (1928:283) 
Bunche: To the Togolese, the French in Togo are merely some more colonial administrators with a new and strange language and a knack for collecting taxes. In truth, this new status means little to them now and will continue so for many years. (1934:138)

In effect, Bunche is having a debate with Buell framed by three questions: What is the relevant knowledge when comparing the mandate system to pure colonialism? Who gets to make that determination, and on what basis?

\section{Ethnographic Fieldwork in Colonial Kenya: Bunche and Kenyatta}

Bunche's last scholarly publication on Africa was his article "The Irua Ceremony among the Kikuyu of Kiambu District, Kenya" (1941), which appeared the year he took a partial leave from Howard to begin working for the federal government in the Office of Strategic Services (the precursor to the CIA). This article evokes, without explicitly mentioning it, Jomo Kenyatta's well-received book Facing Mount Kenya (1978 [1938]). In a thinly veiled reference to Kenyatta's cultural defense of female circumcision, Bunche presents his own ethnographic description of a ceremony that mutilates young girls, reveals a loss of cultural knowledge, and countenances economic extortion by an old woman who performs the procedure on a girl deemed unsuitable. Ironically, Bunche's access to this ceremony was mediated through Kenyatta, who was his Swahili teacher during a 1937 postdoc spent at the London School of Economics studying anthropology with Bronislaw Malinowski. Kenyatta had arranged for Bunche to meet the leaders of the Kikuyu Central Association, who in turn negotiated permission for him to witness and film an initiation ceremony.

In the article, Bunche agrees with Kenyatta that land alienation and a rising nationalist sentiment were the critical issues in colonial Kenya. But he insisted that these issues should be fought in the political arena, and not worked out on the bodies of young girls. A close, side-by-side reading of Kenyatta's and Bunche's texts reveals that Bunche framed a debate with Kenyatta around three questions: What should be the relevant knowledge about Africa? Who gets to make that determination, and on what basis? Note how his ethnographic account tacks back-and-forth with that of Kenyatta's text:

Kenyatta: The reader will undoubtedly wish to know my credentials for writing the book.... In the present work I have tried my best to record facts as I know them, mainly through a lifetime of personal experience... I received the usual education of Gikuyu boys.... I participated in the activities of my age-group, and was chosen as its leader. The writer has learned [facts about the initiation of girls] from several girls (relatives and close friends) who have gone 
through the initiation and who belong to the same age-group as the writer. (1978[1938]:147)

Bunche: This paper [includes] a... summary description of an irua ceremony which I had the privilege to witness at Githiga Market, in the Kiambu District of Kenya, in February 1938. It was only with difficulty that I gained permission to take pictures of it, despite the fact that I had been introduced into the tribe, and given the name Karioki. Since there were 12 girls and only one boy in the group, I will confine myself mainly to an account of the activities of the girls... It is to be noted that the ceremonies vary in detail from one locality to another. (1941:53-54)

Kenyatta (describing the operation): A woman specialist, known as moruithia, who has studied this form of surgery from childhood, dashes out of the crowd, dressed in a very peculiar way, with her face painted with white and black ochre.... She takes out from her pocket... the operating Gikuyu razor (rwenji), and in a quick movement, and with the dexterity of a Harley Street surgeon, proceeds to operate upon the girls. With a stroke she cuts off the lip of the clitoris.... As no other part of the girl's sexual organ is interfered with, this completes the girl's operation. (1978[1938]:146)

Bunche: The female operator, the moruithia wa irigu, an old haggish looking woman, with one tooth prominently showing, and armed with a small Kikuyu razor (rwenji), resembling somewhat in size and shape our safety razor blade, began her work. With a deft strike she hacked off the tip of the clitoris... and a bright patch of red immediately appeared, as the sponsors held the girls more tightly. The labia minora of each girl was also trimmed, though it is said that formerly the operation was confined to the amputation of the clitoris.... All went well... until the last girl was reached. Here a complication arose. The moruithia bent down, examined the girl carefully, muttered to herself, and shook her head. It seemed that there was some abnormality about the girl. The sponsor of the girl burst into tears, and after a short conference the moruithia proceeded with the operation.... The usual fee charged... is $3 /$ - for girls and $4 /$ - for boys.... But the parents of the girl with the abnormality were required to pay 20/- or one fat ram. (1941:61)

Kenyatta (describing what happens once the operation is over): At the time of the surgical operation the girl hardly feels any pain for the simple reason that her limbs have been numbed, and the operation is over before she is conscious of it. It is only when she awakes 


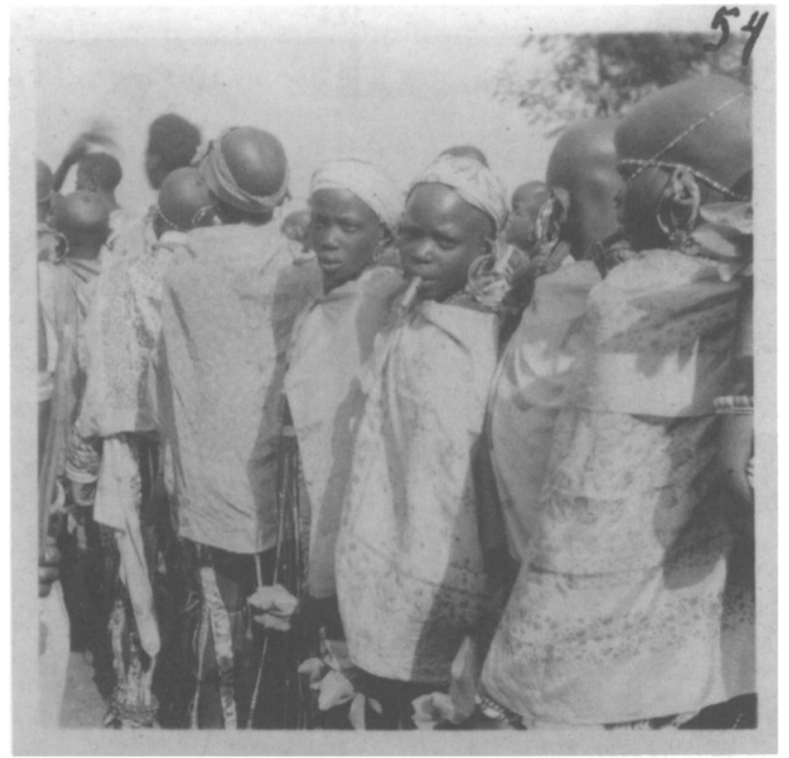

Photo taken by Ralph Bunche of Kikuyu girls at Githiga Market, in the Kiambu District of Kenya, as they await the final phase of their initiation ceremony, February 1938. Photograph courtesy of the Schomburg Center for Research in Black Culture.

after three or four hours of rest that she begins to realize that something has been done to her genital organ. (1978[1934]:147)

Bunche: As soon as the last girl was cut the crowd surged forward and wild dancing and shouting ensued. Then the girl initiates, still naked from the waist down, acquired long sticks, and ... began running about recklessly, chasing the older, circumcised boys and girls who had earlier taunted the initiates... and who had threatened to beat them if they showed cowardice. Now... the initiates... were entitled to run after and beat their tormentors with sticks. Blood poured down their legs as they ran, and some seemed quite vicious about it all, probably due to the excruciating pain they must have experienced. (1941:62)

Bunche acknowledged that the four-and-a half-hour ceremony was "the most gruesome, bloody spectacle I have ever seen" (Henry 1999:84). However, he concludes his article by giving the final word to Senior Chief Koinange of Kiambu district, taken from excerpts of his biographical notes.

Bunche (quoting Chief Koinange): "I do not approve of the circumcision of girls, since I do not believe that it does the girl any good to be circumcised. On the other hand I dislike the methods employed by the Europeans in trying to force us to abolish the custom.... If the girls are properly educated, the more education they will get the more they will find that circumcision has no bearing on their 


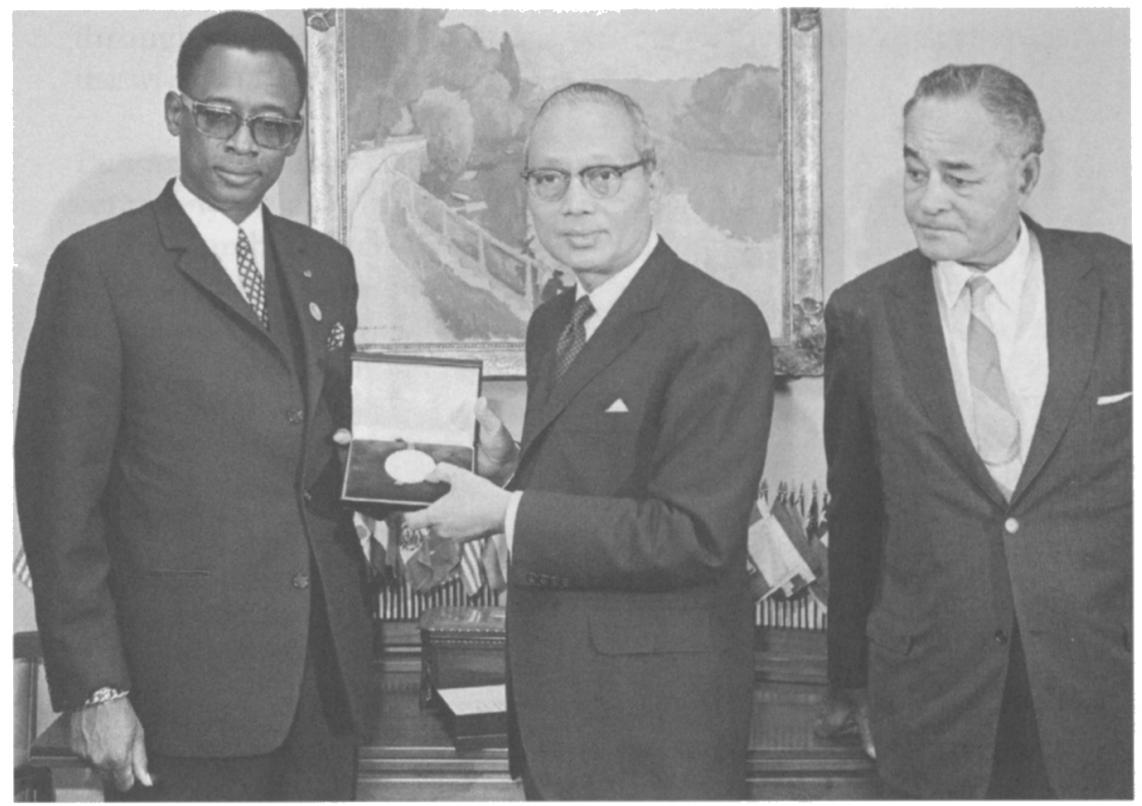

U.N. Secretary-General U Thant presents Joseph Mobutu (left), President of the Democratic Republic of Congo, with a United Nations 25th Anniversary Commemorative medal. At the right is Ralph J. Bunche, Under Secretary-General for Special Political Affairs, October 8, 1970. Photograph courtesy of the United Nations.

lives, and they will stop it voluntarily... Most people accept circumcision blindly as an old custom. Three of my own daughters are circumcised, but the two younger ones are not. One who was not circumcised is already married and is bearing children. I believe that it should be left to the girls themselves to decide. I do not want any of my daughters forced into either circumcision or marriage or forced to forgo them, against their desires." (1941:64-65)

One can't help thinking that Bunche is expressing his personal view about the prospect of his own two daughters' going through the Irua ceremony that he had witnessed and recorded among the Kikuyu of Kiambu District in Kenya. But he uses the device of quoting a Kikuyu chief to trump Kenyatta's claim of authenticity for his data, of the benign consequences of this practice for the girls who undergo the operation, and, ultimately, of the importance of the ceremony to the maintenance of Kikuyu cultural identity. Bunche states clearly, in his own voice, that "the circumcision rites [became] accentuated as an emblem of national self-assertion and a recompense for lost power" (1941:52). However, at this phase of his career he shows the need to corroborate conclusions drawn from his participant- 
observation data with the testimony of a Kikuyu who is cast as a cultural authority and "one of the wisest philosophers I have ever met" (1941:64).

\section{Crisis in the Congo: The Politics of Knowledge}

Nineteen years later, when Bunche, the international civil servant, found himself temporarily at the helm of the U.N. Operation in the Congo, his colleagues knew him to be an expert on Africa, and assumed this meant that he had the relevant knowledge to manage a complex, escalating crisis. His success and reputation within the U.N. system as a globe-trotting troubleshooter and effective mediator were reasons for further assurance.

Bunche was still wedded to the paradigm of the Talented Tenth, and that was a nonstarter for the situation in the Belgian Congo. At the time of independence in 1960, only seventeen Congolese had university degrees, and there was not one Congolese officer in the Congolese army. Given the political impasse separating President Joseph Kasavubu and Prime Minister Patrice Lumumba, and given Bunche's personal view that Lumumba was ill-suited for the daunting challenges of political leadership in a high stakes crisis, Bunche shouldered the burden of determining the best interests of the Congo. But unlike Bunche, the Africanist, who insisted on the necessity of taking into account "the pressure of forces of an outside world which is itself in process of transformation" as well as the native's "own ideas and ideals," (1934:74), Bunche, the U.N. representative, was unable to master the competing contingencies of Cold War politics that radically transformed the local terrain. Bunche began his assignment with optimism and hope, telling a journalist on assignment for Ebony magazine that "the United Nations force in the Congo is unique, because it is in direct and constant touch with the populace of the country" (Morrison 1960). In reality, the dearth of local knowledge available to the U.N. staff meant that decisions were often taken divorced from a nuanced understanding of the local context.

Ralph Bunche died on December 12, 1971. A year earlier, when the U.N. celebrated its twenty-fifth anniversary, Joseph Mobutu, president of the Democratic Republic of the Congo, paid an official visit to the headquarters in New York. He was guest of honor at a luncheon given by Secretary-General U Thant and presented with a U.N. commemorative medal. Bunche, as Under Secretary-General for Special Political Affairs, was obliged to share the spotlight with the Congolese dictator who had seized power during the UNOC deployment. That diplomatic ritual must have been a bitter pill to swallow.

Toward the end of his life Bunche spent a good deal of time reflecting on what it means to be a policymaker with responsibility for decisions that have lasting implications for future generations and life-or-death consequences for large numbers of people. He had less certainty about the project of social engineering. He had come to appreciate that knowledge per se is fleeting, and that what matters is less what you know, but rather, how readily you are able to absorb new information, how effectively you can 
analyze problems and evaluate solutions, and how much access you have to locally produced knowledge that comes from sources other the intelligence services. Africanist expertise is not a one-person pursuit. These lessons have special relevance for any Africanist who moves into policymaking positions.

\section{African Studies: The Way Forward}

When the first annual meeting of the ASA convened at Northwestern University in 1958, the attendees included scholars and educators from a variety of disciplines; a few lawyers, engineers, and members of missionary societies; along with a scattering of foundation, government, and U.N. officials. The founders insisted that an emphasis on scholarship should be paramount. And Melville Herskovits used the occasion of his presidential address to stake out a special position for the American Africanist, who, he contended, was "removed in space from the African scene" and had "no territorial commitments in Africa." By Herskovits's reckoning, these attributes provided "a certain physical and psychological distance" that naturally facilitated "a heightened degree of objectivity" so necessary to the scholarly enterprise (in Gershenhorn 196).

Today the American Africanist community comprises significant numbers of Africans who are citizens or permanent residents of the United States. And roughly 3 percent of the ASA's membership resides in Africa. While our identity as a learned society remains anchored by a preponderance of U.S.-based academics and students, our annual meeting program regularly slates panels that include journalists, human rights activists, policy analysts, health practitioners, government officials, diplomats, and scholars from overseas. This diversity of background and perspectives has significantly enriched the field of African studies.

To build on this strength, the ASA's second fifty years should be marked by the consolidation of strong, broad, and deep linkages with greater numbers of scholars and institutions based on the African continent. Our association is now well positioned to facilitate transcontinental communications and collaboration among scholars engaged in the production and dissemination of knowledge in and about Africa. Toward this end, the ASA board is already working with African partners to develop a long-term initiative that would operate through networks designed to facilitate the globalization of Africa-centered, Africa-generated knowledge. As we move forward, let us be mindful of the need to build a truly collaborative endeavor-one that is informed by the many lessons of Ralph Bunche's African odyssey.

\section{Acknowledgments}

I gratefully acknowledge UCLA's Globalization Research Center-Africa, and its director, Edmond Keller, for support that enabled me to spend a month 
as a 2005 visiting fellow doing archival research at the Charles E. Young Research Library, Department of Special Collections. I would also like to thank the James S. Coleman African Studies Center, UCLA, for providing me with a welcoming home as a visiting scholar while I consulted the Ralph Bunche Papers. This lecture is dedicated to the memory of my two African studies mentors: Donald Rothchild (Professor of Political Science, University of California at Davis), and Elliott P. Skinner (Franz Boas Professor of Anthropology Emeritus, Columbia University).

\section{References}

Buell, Raymond Leslie. 1928. The Native Problem in Africa. Volume 2. New York: The Macmillan Company.

Bunche, Ralph J. 1934. "French Administration in Togoland and Dahomey." Ph.D. diss., Harvard University. Harvard University Archives. . 1941. "The Irua Ceremony among the Kikuyu of Kiambu District, Kenya." Journal of Negro History 26: 46-65.

Du Bois, W.E.B. 1903. "The Talented Tenth." In The Negro Problem: A Collection of Articles by Representative African Americans of Today, 33-75. New York: James Pott and Company.

Edgar, Robert R., ed. 1992. An African American in South Africa: The Travel Notes of Ralph J. Bunche, 28 September 193-1 January 1938. Athens: Ohio University Press.

Gershenhorn, Jerry. 2004. Melville J. Herskovits and the Racial Politics of Knowledge. Lincoln: University of Nebraska Press.

Henry, Charles P. 1999. Ralph Bunche: Model Negro or American Other? New York: New York University Press.

Holloway, Jonathan Scott. 2002. Confronting the Veil: Abram Harris Jr., E. Franklin Frazier, and Ralph Bunche, 1919-1941. Chapel Hill: University of North Carolina Press.

Kenyatta, Jomo. 1978 (1938). Facing Mount Kenya: The Traditional Life of the Gikuyu. Nairobi: Kenway Publications.

Morrison, Allan. 1960. "Ralph Bunche Tells about His Toughest Assignment." Ebony Magazine, November, 34-36.

Myrdal, Gunnar. 1944. An American Dilemma: The Negro Problem and Modern Democracy. Volumes 1 \& 2. New York: Harper \& Row.

Rivlin, Benjamin, ed. 1990. Ralph Bunche: The Man and His Times. New York: Holmes \& Meier.

Urquhart, Brian. 1993. Ralph Bunche: An American Odyssey. New York: W.W. Norton \& Company.

\section{Notes}

1. Schomburg Center for Research in Black Culture, Ralph Bunche Papers (RBP)-Additions, Box 3/ folder: Selected Cables 30/8/60-30/9/60.

2. This section on Ralph Bunche, the Africanist, draws on my paper "Ralph Bunche the Africanist: Remembering Paradigms Lost." 
3. Ralph J. Bunche, "Letter to Dr. William E.B. Du Bois," May 11, 1927. Reprinted in Rivlin (1990:218).

4. Raymond Buell to Alain Locke, October 2, 1928. Alain Locke Papers, Box 164-18 (Correspondence Buck-Butler). Moorland-Spingarn Research Division, Manuscript Division, Howard University.

5. Harvard Department of Government to Ralph Bunche, October 6, 1933, Box 67, RBP, UCLA. 